\title{
A Comparative Study: Energy Performance Analysis of Conventional Office Buildings at Lucknow
}

\author{
${\text { Farheen } \text { Bano }^{1 *} \text {, Vandana Sehgal }}^{2}$ \\ ${ }^{1}$ Assistant Professor, Faculty of Architecture and Planning, Dr. A.P.J. Abdul Kalam Technical \\ University, Lucknow \\ 2 Principal \& Dean (Professor), Faculty of Architecture and Planning, Dr. A.P.J. Abdul Kalam \\ Technical University, Lucknow. \\ I* bano.farheen@foaaktu.ac.in,
}

Received: $29^{\text {th }}$ April $2019 \quad$ Final version received: $21^{\text {th }}$ April 2020

In this study, the energy consumption of three government and three private office buildings in Lucknow was investigated, and the energy performance index (EPI) for each building was determined. The main purpose of this research was to assess the energy usage of the buildings and identify factors affecting the energy usage. An analysis was performed using data from an energy audit of government buildings, electricity bills of private office buildings, and an on-site visit to determine building envelope materials and its systems. The annual energy consumption of buildings has been evaluated through EPI. The EPI, measured in kilowatt hour per square meter per year, is annual energy consumption in kilowatt hours divided by the gross floor area of the building in square meters. In this study, the energy benchmark for day-time-use office buildings in composite climate specified by Energy Conservation Building Code (ECBC) has been compared with the energy consumption of the selected buildings. Consequently, it has been found that the average EPI of the selected buildings was close to the national energy benchmark indicated by ECBC. Moreover, factors causing inefficient energy consumption were determined, and solutions for consistent energy savings are suggested for buildings in composite climate.

Keywords: Energy efficiency: Office building; Energy performance index; Energy audit; Solar passive features

\section{INTRODUCTION}

A steady increase in the construction of tall buildings has occurred in fast-growing cities in India, such as Lucknow, because of rapid urban population growth, limited land, and globalization. Many low performance buildings are present and growing in the city regardless of environmental concerns over energy scarcity and global warming. Consequently, within a certain period, most of the current office buildings in Lucknow consume energy inefficiently because of the absence of energy optimization measures in them. This causes a significant increase in recurring expenditures because of high energy consumption.

Several studies have examined the impact of design strategies on the energy consumption of high rise office buildings (Table 1). Esfandiari et al. (2017) and Ismail et al. (2006) compared the indoor temperature and air quality with user satisfaction of bioclimatic and conventional high-rise office buildings located in Penang Island. They observed that bioclimatic high-rise office buildings had comfortable indoor conditions and high user satisfaction. However, the energy performance of bioclimatic and conventional high-rise office buildings was not considered. Thus, a holistic approach for analysing a high-rise building is required to evaluate the energy performance associated with design strategies. Mahdavi et al. (2013) established the optimal value of Window-to-Wall Ratio (WWR) pertaining to daylight in office buildings without considering thermal comfort. Therefore, an holistic approach is required to study the effect of all passive design feature on 
thermal comfort and energy efficiency of an office building.

Tahir, Nawi, and Rajemi (2015) analyzed the pattern of electricity consumption in three government office buildings and investigated the factors contributing to inefficient energy consumption. Moreover, they concluded that further investigation was required to determine energy breakdown usage in detail. Raji et al. (2016) compared 12 buildings from three climate groups (temperate, subtropical, and tropical) to study the effectiveness of different design strategies for decreasing energy usage for cooling, heating, ventilation, and electric lighting. They recommended the performance of an additional study for tropical areas to frame design consideration for high-rise buildings.

Limited in-depth studies are available regarding design strategies for making conventional buildings efficient and the energy breakdown usage of tall office buildings in a tropical climate. Consequently, this study aims to develop an overarching framework to investigate the factors affecting the energy usage of office buildings in Lucknow (composite climate sub-category of tropical climate). The outcome of this study provides an insight regarding the reasons for high energy consumption. Moreover, suitable energy efficiency measures are suggested for buildings located in Lucknow.

Table 1: Review of related literature

\begin{tabular}{|c|c|c|c|}
\hline Author/Reference & Objective & Findings & Scope for future study \\
\hline $\begin{array}{l}\text { Esfandiari, Zaid, } \\
\text { and Ismail (2017) }\end{array}$ & $\begin{array}{l}\text { To establish the } \\
\text { relationship between the } \\
\text { indoor air quality and user } \\
\text { satisfaction (thermal } \\
\text { comfort. Health and } \\
\text { productivity) }\end{array}$ & $\begin{array}{l}\text { Green buildings have } \\
\text { better indoor air quality } \\
\text { and user satisfaction; } \\
\text { however, the minor fault } \\
\text { leads to dissatisfaction. }\end{array}$ & $\begin{array}{l}\text { The building construction } \\
\text { related parameters should } \\
\text { be studied in detail to } \\
\text { characterise the effect of } \\
\text { each parameter. }\end{array}$ \\
\hline $\begin{array}{l}\text { Raji, Tenpierik, } \\
\text { and Dobbelsteen } \\
(2016)\end{array}$ & $\begin{array}{l}\text { To perform a comparative } \\
\text { study on } 12 \text { buildings } \\
\text { from three climate groups } \\
\text { (temperate, subtropical, } \\
\text { and tropical) for } \\
\text { investigating the } \\
\text { effectiveness of different } \\
\text { design strategies for } \\
\text { overall reduction energy } \\
\text { consumption in heating, } \\
\text { cooling and lighting. }\end{array}$ & $\begin{array}{l}\text { Lessons obtained from } \\
\text { these buildings were used } \\
\text { to define passive features } \\
\text { for the three climate } \\
\text { groups. }\end{array}$ & $\begin{array}{l}\text { The results indicated that } \\
\text { for tropics, additional } \\
\text { studies are required } \\
\text { regarding the design of } \\
\text { high-rise buildings. }\end{array}$ \\
\hline $\begin{array}{l}\text { Tahir, Nawi, and } \\
\text { Rajemi (2015) }\end{array}$ & $\begin{array}{l}\text { To analyze the pattern of } \\
\text { electricity consumption in } \\
\text { three government office } \\
\text { buildings. }\end{array}$ & $\begin{array}{l}\text { Energy savings can be } \\
\text { achieved by implementing } \\
\text { an energy-efficient design } \\
\text { in the early stage of } \\
\text { construction. }\end{array}$ & $\begin{array}{l}\text { Further investigation is } \\
\text { required to determine } \\
\text { energy breakdown usage } \\
\text { in detail. }\end{array}$ \\
\hline $\begin{array}{l}\text { Mahdavi, Rao, and } \\
\text { Inangda (2013) }\end{array}$ & $\begin{array}{l}\text { To investigate the effect } \\
\text { of WWR for optimising } \\
\text { daylight in office } \\
\text { buildings. }\end{array}$ & $\begin{array}{l}25 \% \text { WWR found to be } \\
\text { optimum for horizontal } \\
\text { fenestrations and } 35 \% \text { for } \\
\text { vertical. }\end{array}$ & $\begin{array}{l}\text { Holistic approach should } \\
\text { be applied to investigate } \\
\text { the optimum daylight as } \\
\text { well as thermal comfort } \\
\text { with respect to WWR in } \\
\text { an office building. }\end{array}$ \\
\hline $\begin{array}{l}\text { Ismail and Sibley } \\
(2006)\end{array}$ & $\begin{array}{l}\text { To compare the } \\
\text { performance, indoor } \\
\text { temperature, and user } \\
\text { perception of a high-rise } \\
\text { bioclimatic office block } \\
\text { designed by Ken Yeang } \\
\text { with those of a } \\
\text { conventional office } \\
\text { building. }\end{array}$ & $\begin{array}{l}\text { Bioclimatic high-rise } \\
\text { office buildings had } \\
\text { comfortable indoor } \\
\text { conditions and high user } \\
\text { satisfaction. }\end{array}$ & $\begin{array}{l}\text { The study does not } \\
\text { evaluate the energy } \\
\text { performance } \\
\text { bioclimatic of } \\
\text { conventional high-rise } \\
\text { office buildings. Thus, a } \\
\text { detailed study is required } \\
\text { to evaluate energy } \\
\text { performance. }\end{array}$ \\
\hline
\end{tabular}




\section{METHODOLOGY}

In this study, the energy performance of six (three government and three private) conventional office buildings in Lucknow was examined by focusing on the electricity usage pattern (Figure 1), and the causes of high energy consumption were investigated. Moreover, suitable measures are suggested to decrease energy consumption. The selected cases represent a sample of almost all upcoming office buildings in the city. The selection criteria for the case studies were as follows:

- Energy use indices higher than 100 $\mathrm{kW} / \mathrm{m}^{2} /$ year and having daytime working hours.

- Typical floor area ranging from 700 to $2000 \mathrm{~m}^{2}$, with the air-conditioned space exceeding $50 \%$.

- Comprising eight or more floors.

- Developed in a time period of 19892014 , located in an iconic area that represents the image of Lucknow.

- To expand the analysis, plans with different aspect ratios were considered.

Data regarding the electricity consumption, floor plans, working hours, building envelope materials, and schedules of occupancy and equipment were collected through on-site survey for the selected buildings. To determine the reasons for high electricity consumption in buildings, the selected buildings were compared according to the shape and form of the buildings, WWR, materials used in the building envelope, presence of passive features (if any), and location of the core. Moreover, the energy usage of conventional office buildings in Lucknow was benchmarked. That benchmark can be further used for comparing the energy savings of energy-efficient buildings in Lucknow. Moreover, the representation model of a typical office building in Lucknow, derived from the average of the surveyed data for the six selected office buildings, can be used create base-case in energy simulation studies.

Office buildings in Lucknow consumes energy in the form of electricity for mechanical and electrical systems, such as artificial lighting, heating, ventilation and air conditioning (HVAC) (UP Power Corporation Limited, 2015). HVAC, lighting, and equipment loads were examined to analyse the energy usage pattern of an office building and calculated in terms of the energy performance index (EPI). The EPI (measured in $\mathrm{kWh} / \mathrm{m}^{2} /$ year) is commonly used for comparing the energy consumption of buildings. "It is the annual energy consumption of a building in kilowatt-hours divided by gross floor area of the building in square meters" [Eq. (1)] (Srinivas, 2015).

$\mathrm{EP}=\frac{\text { Total energy consumed in a year }(\mathrm{kWh})}{\text { Total floor area of the building }\left(\mathrm{m}^{2}\right)} \ldots \ldots$

\section{BUILDING PROFILE OF THE SELECTED CONVENTIONAL OFFICE BUILDINGS IN LUCKNOW}

The study focuses on Lucknow city $\left(26^{\circ} 30^{\prime}-\right.$ $27^{\circ} 0^{\prime} \mathrm{N}$ and $80^{\circ} 30^{\prime}-81^{\circ} 13^{\prime} \mathrm{E}$ ), which is the capital of Uttar Pradesh, India. It lies in a composite climate zone of India (tropical climate), which is categorized by extremely high and low temperatures in summers and winters, respectively. Summers are marked by high direct solar radiation, low humidity, and hot winds, whereas winters are marked by low temperatures, high humidity, and cold winds. Moreover, humidity is high in monsoon with strong winds. The details of the buildings and their building profile and energy consumption data are summarized in Tables 2 and 3. The operational hours of the government office buildings, namely Shakti Bhawan, Uttar Pradesh Rajkiya Nirman Nigam (UPRNN), and Lucknow Development Authority (LDA), are from 9 am to $5 \mathrm{pm}$ for six days a week, and the buildings occupy 1100,475 , and 1350 staff, respectively. Shalimar Titanium, the Bank of Baroda (BOB) office, and Eldeco Corporate Chamber II were the private office buildings selected for the study. These buildings currently cater to 1424 , 1578, and 997 staff, respectively, whose working hours are from 9 am to $6 \mathrm{pm}$ (Tables 1 and 2). 


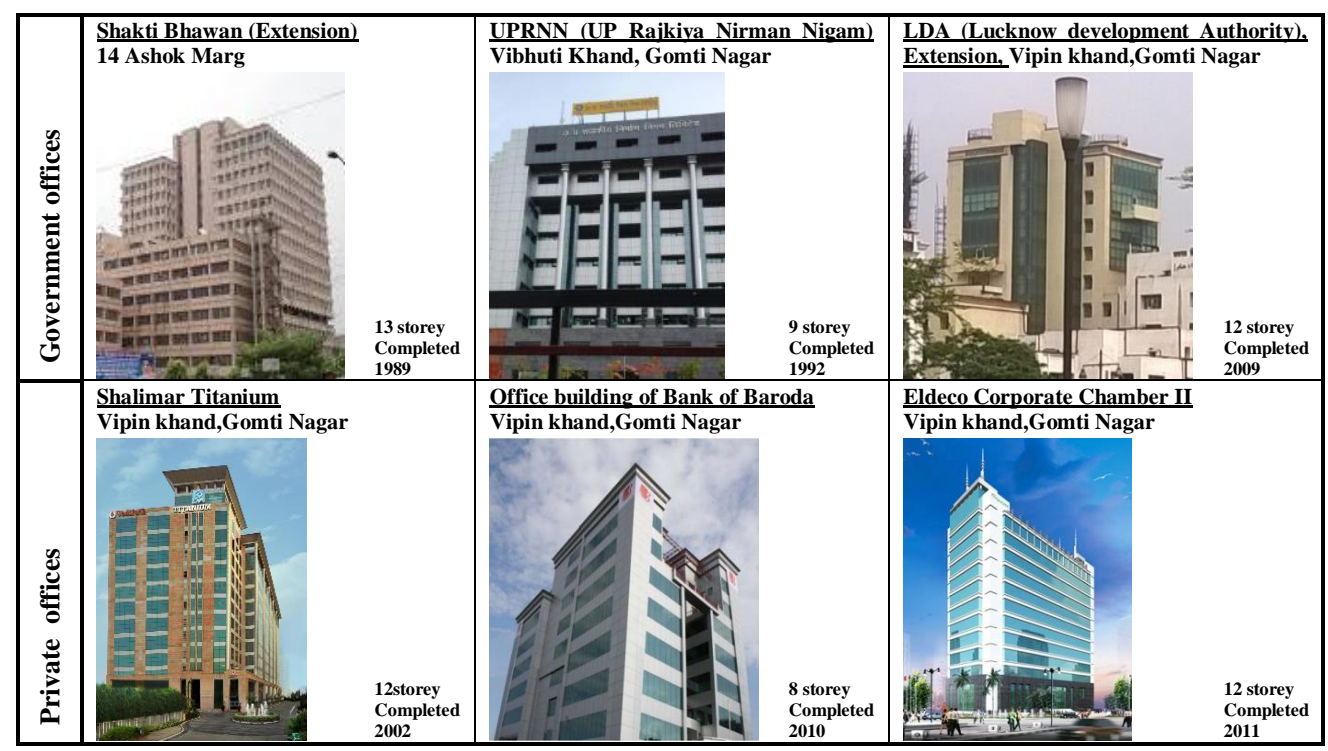

Figure1. The six selected buildings in Lucknow (Source: Author)

\subsection{Building configuration}

The buildings are oriented and configured according to the urban grid and plot size, with the aim of maximizing the view. Environmental concerns were not taken into account during the construction of the buildings. Shakti Bhawan, the LDA building, and Shalimar Titanium have an east-west orientation. However, the I-shape of Shakti Bhawan and LDA building allows maximum windows in north and south directions, with the core in the center. By contrast, the rectangular shape (aspect ratio of 1:2) of the fully glazed Shalimar Titanium building exposes a long facade in the east-west direction, thereby increasing the cooling load. The UPRNN office building has a square shape, and the BOB office building has a rectangular shape (aspect ratio of 1:1.5 and oriented northsouth). A void in the center of the BOB and UPRNN buildings reduces the plan depth and allows deep penetration of daylight. Eldeco Corporate Chamber II has a rectangular shape, with an aspect ratio of 1:2.5. The plan depths of Shakti Bhawan, the LDA building, Shalimar Titanium, and Eldeco Corporate Chamber II are $12,14,32$, and $17 \mathrm{~m}$, respectively, between the facades, whereas the UPRNN and BOB buildings have a plan depth of $10 \mathrm{~m}$ from the void. (Tables 2 and 3 ).

\subsection{Window parameters}

The selected government office buildings have a low WWR range of $20 \%-25 \%$, with a recessed window of $450 \mathrm{~mm}$ depth, whereas the selected private offices have a high WWR range of $50 \%-60 \%$, without any shading devices (Tables 2 and 3).

\subsection{Envelope materials}

No special considerations were taken to reduce heat transfer from the building envelope of the selected buildings. Conventional materials and techniques were employed to construct the envelope, specifically a $120-\mathrm{mm}$ brick wall, a 150-mm RCC roof, and 6-mm glass fitted in aluminum frames. Mud + husk composite terracing (locally called mud phuska) was used in Shakti Bhawan whereas, in the UPRNN and LDA buildings, 40-mm vitrified tiles on reinforced cement concrete (RCC) slab was laid. Stone and aluminum cladding panel (ACP) cladding were applied on the walls of the UPRNN, Shalimar Titanium, BOB, and Eldeco Corporate Chamber II office buildings. The selected private offices and the LDA building have windows with reflected glass. Tinted and clear glasses are used in the BOB building and Shakti Bhawan (Tables 2 and 3), respectively.

\subsection{Energy consumption}

Central air conditioning systems are used in almost all the selected office buildings, excluding the UPRNN building, where split and window ACs are used for air conditioning the individual rooms. The energy consumption data for the government office buildings were obtained from energy audit reports, whereas that of private offices were obtained from electricity bills. The annual electricity consumption of the Shakti Bhawan, UPRNN, and LDA buildings 
was 135,125 , and $148 \mathrm{kWh} / \mathrm{m}^{2}$, respectively. The annual energy consumption of the Shalimar Titanium, BOB, and Eldeco Chamber buildings was 257,167 , and $228 \mathrm{kWh} / \mathrm{m}^{2}$, respectively.

\section{FINDING AND DISCUSSION}

All the six office buildings lack any energyefficient design measures and an energy management program. Conventional materials were used for the construction of the building envelope, and no additional measures were taken to reduce heat gain or loss. Overall, the energy consumed by the six buildings is mainly used for the air conditioning system, lighting system, and office equipment.

\subsection{Building configuration}

The electricity consumption of the selected government offices was obtained from the energy investment grade audit report 2009-10, which is a systematic approach to investigate current energy usage (Tahir, Nawi, \& Rajemi, 2015). Maximum electricity was consumed by the air conditioning system, electrical lighting system, and office equipment. For artificial lighting, the buildings mainly used fluorescent tubes, compact fluorescent lamps, tungsten halogen lamps, and LED lamps. A hydronic central air conditioning system with variable air volume (VAV) system is employed in Shakti Bhawan, a unitary system (window and split AC) is employed in the UPRNN building, and Variable refrigerant volume (VRV) system or multiple split AC systems are used in the LDA office building for air conditioning. Figure 2 displays the distribution of energy consumption for the three selected government office buildings.

\begin{tabular}{|lc|c|c|c|c}
\hline \multicolumn{5}{|c}{ Yearly consumption of Electricity in three government office buildings } \\
\hline & & HVAC & Lighting & Others & Total \\
Shakti Bhawan & Kwh & 2083279 & 579420 & 502781 & 3165480 \\
\hline & $\%$ & $66 \%$ & $18 \%$ & $16 \%$ & $100 \%$ \\
\hline UPRNN & Kwh & 189591 & 147812 & 77701 & 415104 \\
\hline & $\%$ & $46 \%$ & $36 \%$ & $19 \%$ & $100 \%$ \\
\hline LDA & Kwh & 661185 & 271825 & 364364.19 & 1297374.2 \\
\hline & $\%$ & $51 \%$ & $21 \%$ & $28 \%$ & \\
\hline AVERAGE & & $\mathbf{5 4} \%$ & $\mathbf{2 5} \%$ & $\mathbf{2 1 \%}$ & \\
\end{tabular}

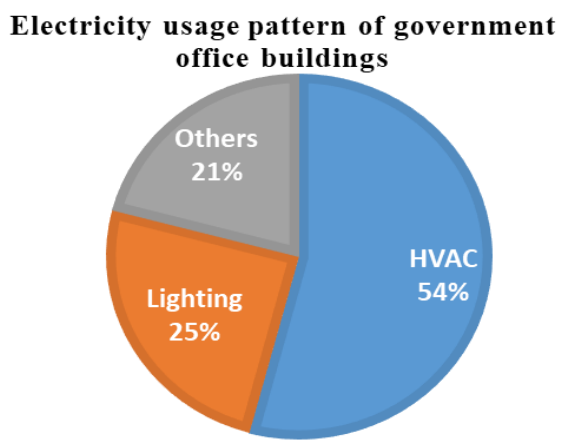

Figure 2. Electricity usage pattern in the government office buildings (source: energy investment grade audit report 2009-10)

Table 2. Details of the three selected government office buildings (source: energy audit reports and surveyed data).

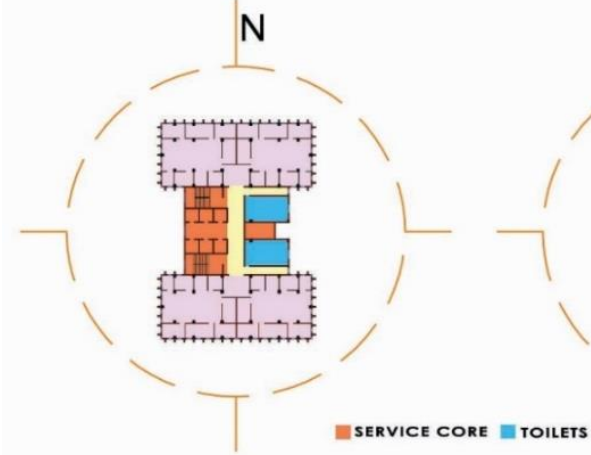

Shakti Bhawan

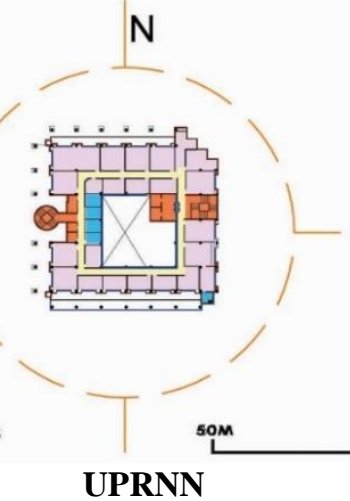

UPRNN

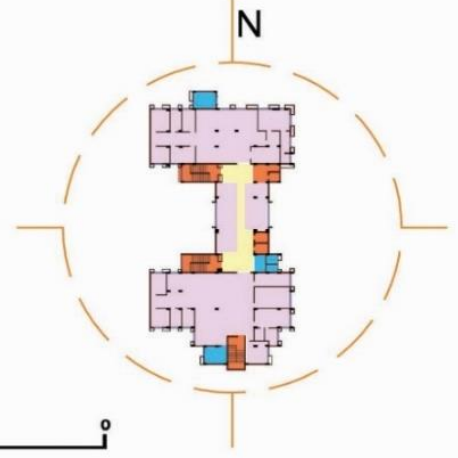

LDA 


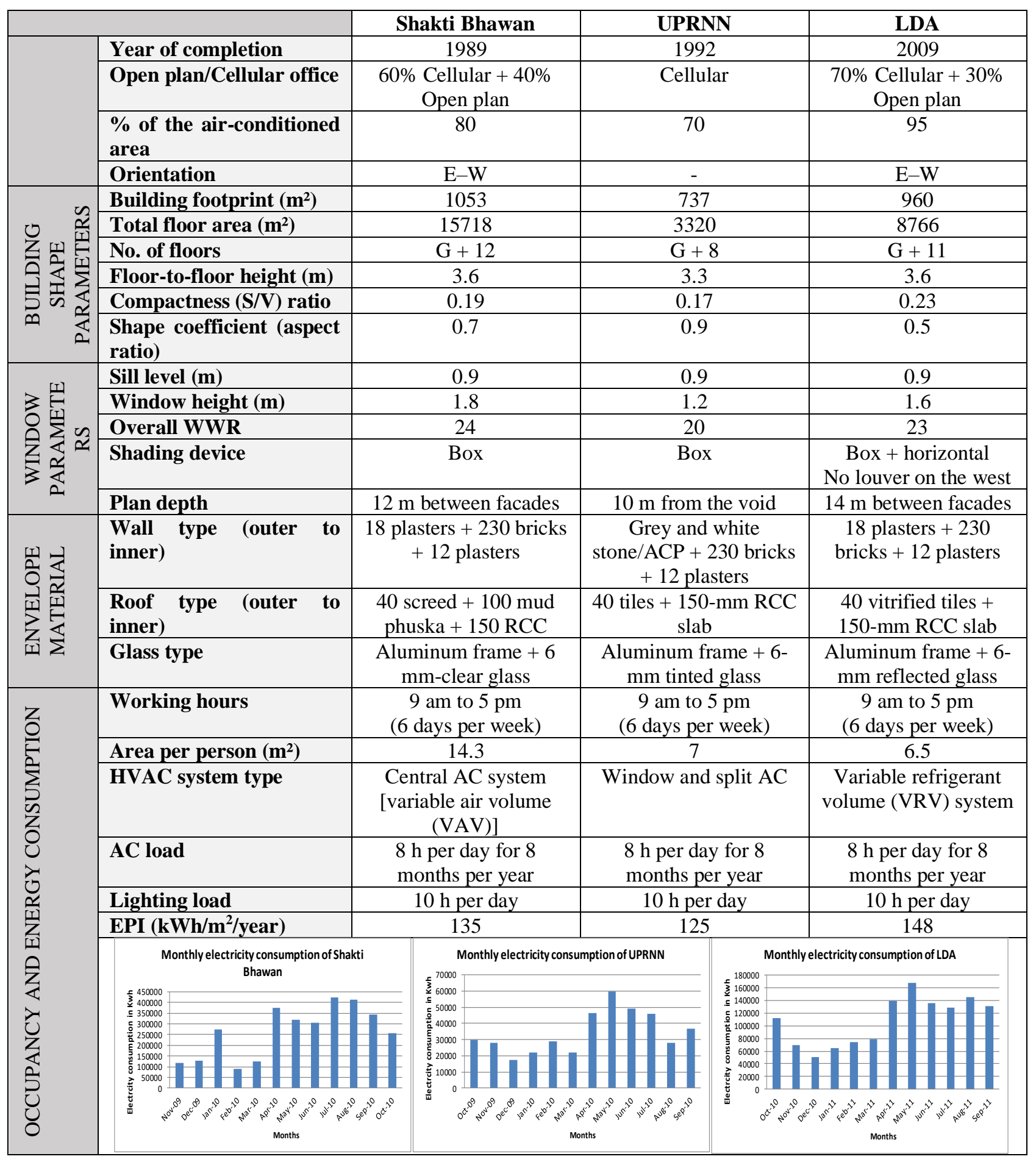


Table 3. Details of the three selected private buildings (source: electricity bills and surveyed data).
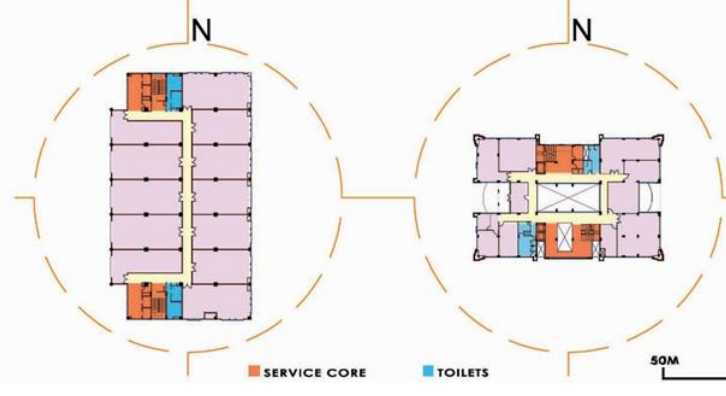

N

Shalimar Titanium

Office building of BOB

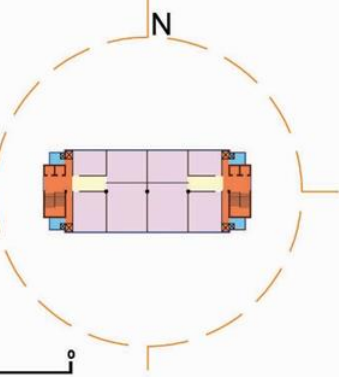

\begin{tabular}{|c|c|c|c|c|}
\hline & & & \\
\hline & & Shalimar Titanium & BOB & Eldeco \\
\hline & Year of completion & 2002 & 2010 & 2011 \\
\hline & $\begin{array}{l}\text { Open } \\
\text { office }\end{array}$ & $\begin{array}{l}40 \% \text { Cellular }+60 \% \\
\text { Open plan }\end{array}$ & $\begin{array}{l}20 \% \text { Cellular }+80 \% \text { Open } \\
\text { plan }\end{array}$ & $\begin{array}{l}60 \% \text { Cellular }+40 \% \\
\text { Open plan }\end{array}$ \\
\hline & $\begin{array}{l}\% \text { of air-conditioned } \\
\text { area }\end{array}$ & $100 \%$ & $100 \%$ & $100 \%$ \\
\hline & Orientation & E-W & $\mathrm{N}-\mathrm{S}$ & $\mathrm{N}-\mathrm{S}$ \\
\hline \multirow{7}{*}{ 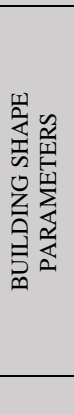 } & Building footprint $\left(\mathrm{m}^{2}\right)$ & 1891 & 1009 & 706 \\
\hline & Total floor area $\left(\mathrm{m}^{2}\right)$ & 22785 & 7889 & 8472 \\
\hline & No, of floors & $\mathrm{G}+11$ & $\mathrm{G}+7$ & $\mathrm{G}+11$ \\
\hline & $\begin{array}{l}\text { Floor-to-floor height } \\
\text { (m) }\end{array}$ & 3.6 & 3.9 & 3.5 \\
\hline & $\begin{array}{l}\text { Compactness }(\mathrm{S} / \mathrm{V}) \\
\text { ratio }\end{array}$ & 0.12 & 0.2 & 0.18 \\
\hline & $\begin{array}{l}\text { Shape coefficient } \\
\text { (aspect ratio) }\end{array}$ & 0.57 & 0.7 & 0.4 \\
\hline & Plan depth $(\mathbf{m})$ & $32 \mathrm{~m}$ between facades & $10 \mathrm{~m}$ from the void & $17 \mathrm{~m}$ between facades \\
\hline \multirow{4}{*}{ 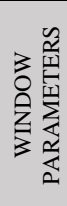 } & Sill level (m) & 0.45 & 0.45 & 0.3 \\
\hline & Window height (m) & 2.25 & 2.25 & 2.4 \\
\hline & Overall WWR & 55 & 31 & 60 \\
\hline & Shading device & No shading & No shading & No shading \\
\hline \multirow{3}{*}{ 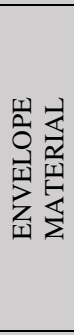 } & $\begin{array}{l}\text { Wall type (outer to } \\
\text { inner) }\end{array}$ & $\begin{array}{c}\text { Stone }+230 \text { bricks }+12 \\
\text { inner plasters }\end{array}$ & $\begin{array}{l}\mathrm{ACP}+230 \text { bricks }+12 \\
\text { inner plasters }\end{array}$ & $\begin{array}{c}\text { Stone /ACP }+230 \\
\text { bricks }+12 \text { inner } \\
\text { plasters }\end{array}$ \\
\hline & $\begin{array}{l}\text { Roof type (outer to } \\
\text { inner) }\end{array}$ & $\begin{array}{c}\text { 150-mm RCC slab, } \\
\text { screed }\end{array}$ & 150-mm RCC slab, screed & $\begin{array}{c}\text { 150-mm RCC slab, } \\
\text { screed }\end{array}$ \\
\hline & Glass type & $\begin{array}{l}\text { Aluminum frame }+6- \\
\text { mm reflected glass } \\
\text { structural glazing }\end{array}$ & $\begin{array}{l}\text { Aluminum frame }+6-\mathrm{mm} \\
\text { reflected glass structural } \\
\text { glazing }\end{array}$ & $\begin{array}{l}\text { Aluminum frame }+6- \\
\text { mm reflected glass } \\
\text { structural glazing }\end{array}$ \\
\hline \multirow{6}{*}{ 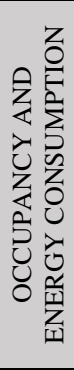 } & Working hours & $\begin{array}{c}9 \text { am to } 6 \mathrm{pm} \\
\text { (6 days per week) }\end{array}$ & $\begin{array}{c}10 \text { am to } 7 \mathrm{pm} \\
(6 \text { days per week })\end{array}$ & $\begin{array}{c}9 \text { am to } 6 \mathrm{pm} \\
\text { (6 days per week) }\end{array}$ \\
\hline & Area per person $\left(\mathbf{m}^{2}\right)$ & 7.1 & 15 & 10 \\
\hline & HVAC system type & VRV system & Central AC system (VAV) & $\begin{array}{c}\text { Central AC system } \\
\text { (VAV) }\end{array}$ \\
\hline & AC load & $\begin{array}{l}8 \mathrm{~h} \text { per day for } 8 \text { months } \\
\text { per year }\end{array}$ & $\begin{array}{l}8 \mathrm{~h} \text { per day for } 8 \text { months } \\
\text { per year }\end{array}$ & $\begin{array}{l}8 \mathrm{~h} \text { per day for } 8 \\
\text { months per year }\end{array}$ \\
\hline & Lighting load & $10 \mathrm{~h}$ per day & $10 \mathrm{~h}$ per day & $10 \mathrm{~h}$ per day \\
\hline & EPI $\left(\mathrm{kWh} / \mathrm{m}^{2} /\right.$ year $)$ & 257 & 167 & 228 \\
\hline
\end{tabular}




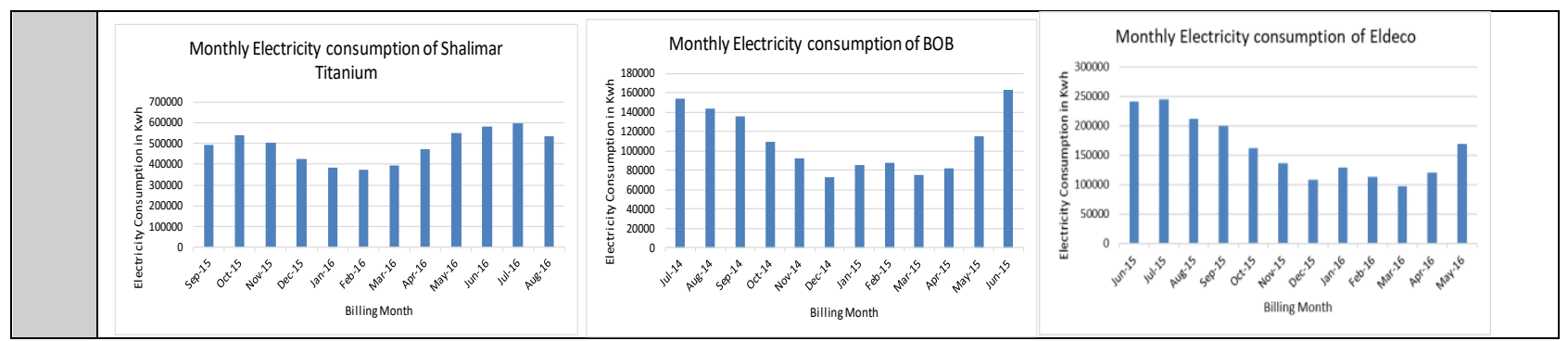

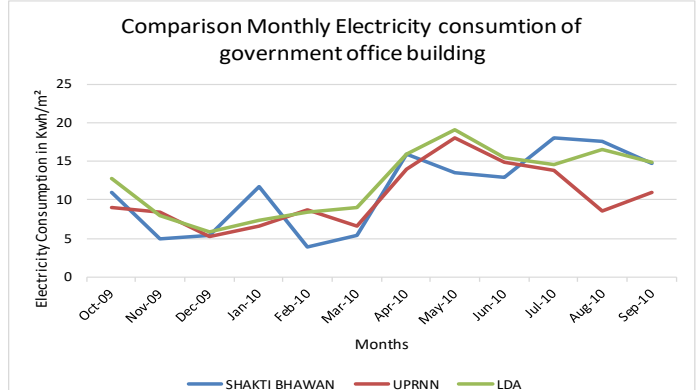

Figure 3. Comparison of the monthly electricity consumption in the government office buildings.

The electricity consumption of the private office buildings was analyzed by collecting their monthly electricity bills from their respective administrative offices. The duration of the collected bills was from January to December (2014-15). (Hence, no separate data for HVAC or lighting systems were available.) Almost $100 \%$ of the building area in the three buildings, including the circulation areas and staircases but excluding the toilets, is air-conditioned. Fluorescent tubes, compact fluorescent lamps, and LED lamps are used for artificial lighting, and a central VRV system is used for air conditioning.

The energy consumption of the three private office buildings was steady throughout the year, with a marginal decrease in consumption in December, January, March, and April (Figure 4).

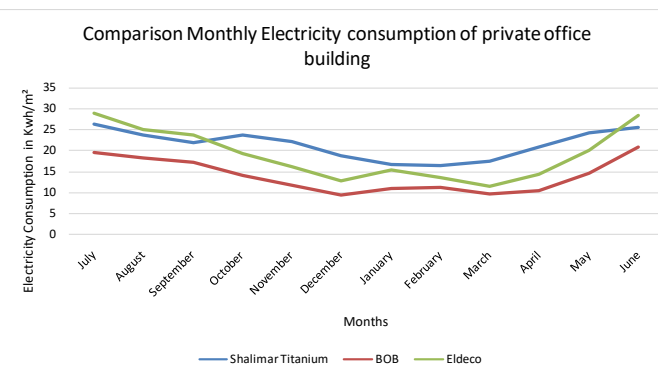

Figure 4. Comparison of the monthly electricity consumption in the private office buildings.

\subsection{Factors affecting energy use in buildings}

Government offices consume less energy than private offices because their WWR is less than that of private offices. Government offices have recessed windows that provide shade, whereas private offices are glass boxes with no shading. Moreover, the mixed-mode system is used in government offices, where circulation spaces are naturally ventilated and office spaces are airconditioned. By contrast, private office buildings are fully air-conditioned.

The three government office buildings are oriented in the east-west direction, which is unfavorable for the composite climate of Lucknow and increases the cooling and lighting load of the building. A majority of the windows face east-west, which causes the building to absorb heat from the low-angled morning and afternoon sun (Koenigsberger et.al., 1973). Therefore, large-area windows are recommended to be installed in the north-south direction to avoid heat absorption into the building. The UPRNN building had an EPI of $125 \mathrm{kWh} / \mathrm{m}^{2}$, whereas the Shakti Bhawan and LDA buildings have an EPI of 135 and $148 \mathrm{kWh} / \mathrm{m}^{2}$, respectively (Table 1). The UPRNN building had the lowest energy consumption because of the following possible reasons:

- The aspect ratio of the UPRNN building is close to $1(0.9)$. Hence, the surface area to volume $(\mathrm{S} / \mathrm{V})$ ratio is low, which reduces the heat gain of the building.

- The presence of a courtyard in the middle of the building reduces the lighting load by reducing the plan depth and ventilating the non-air-conditioned spaces.

- The percentage of air-conditioned spaces is low. Window and split ACs are used in individual cabins and can be customized according to the usage. 
Hence, the HVAC load can be decreased.

- The windows are recessed with tinted glass and restrict the entry of direct radiation, thereby decreasing the cooling load.

Furthermore, the electricity consumption of Shakti Bhawan was less than that of the LDA building because of the following possible reasons:

- Both the buildings are $\mathrm{H}$-shaped with the core in the center. However, they have different aspect ratios ( 0.7 for Shakti Bhawan and 0.5 for the LDA building), which causes Shakti Bhawan to have a lower $\mathrm{S} / \mathrm{V}$ ratio than that of the LDA building, thereby reducing the cooling load of the building (Szokolay, 2014).

- The insulation provided by a $100-\mathrm{mm}$ mud phuska in roofing reduces the heat transferred into Shakti Bhawan.

- The air-conditioned area in the LDA building $(95 \%)$ is higher than that in Shakti Bhawan (80\%), which consequently leads to higher electricity consumption in the LDA building.

- Reflective glass is used in the LDA building, which reduces the cooling load but increases the lighting load of the building. The occupants of Shakti Bhawan who work along the clear glass facade can utilize the daylight along with the blinds when required.

The BOB building had an EPI of $167 \mathrm{kWh} / \mathrm{m}^{2}$, and Shalimar Titanium and Eldeco Corporate Chamber II had an EPI of 257 and $228 \mathrm{kWh} / \mathrm{m}^{2}$, respectively (Table 2). The electricity consumption of the $\mathrm{BOB}$ building was lower than that of the other two private offices despite the occupancy, operation, and activity schedule of all the three buildings being similar. Moreover, reflected glass is used in fenestrations, with no other provision for energy efficiency or energy conservation.

- The BOB and Eldeco buildings are oriented in the north-south direction, with most of the windows facing northsouth, which reduces heat transmission in the building from the low-angled east and west sun.
- The WWR of the BOB building is optimum (31\%) as per Mahoney's recommendations (Koenigsberger et. al., 1973) for the climate of Lucknow. Consequently, heat gain is restricted, and sufficient daylight enters the interiors. Moreover, the compact plan and low plan depth $(5 \mathrm{~m})$ because of the presence of a courtyard at the center of the $\mathrm{BOB}$ building reduces the electricity consumption by artificial lighting.

Shalimar Titanium has an east-west orientation, has a WWR of 55\%, has a high plan depth $(16 \mathrm{~m})$, does not have shading devices on its windows, and does not include energyefficient measures. These properties may have augmented the cooling and lighting loads of Shalimar Titanium, which is reflected in its electricity bills. Eldeco Corporate Chamber II has a large WWR (60\%). However, its northsouth orientation and low plan depth $(8.5 \mathrm{~m})$ reduce the cooling and lighting loads, respectively.

\subsection{Comparison with energy benchmarks}

The EPI benchmark for office buildings in composite climates is 86 and $179 \mathrm{kWh} / \mathrm{m}^{2} /$ year if the air-conditioned space is less than $50 \%$ and exceeds 50\%, respectively (ICEEB, 2015). The average EPI of the selected buildings was 177 $\mathrm{kWh} / \mathrm{m}^{2}$, which can be considered the energy benchmark for office buildings in Lucknow. The EPI of $177 \mathrm{kWh} / \mathrm{m}^{2}$ is close to the national benchmark for office buildings in composite climates, with an air-conditioned space exceeding $50 \%$.

The Energy conservation building code (ECBC) standard indices indicate that any building implementing energy-efficient measures can achieve an EPI up to $110 \mathrm{kWh} / \mathrm{m}^{2} /$ year (BEE, 2012). On the basis of this energy range, government office buildings have an energy savings potential of $20 \%-30 \%$, whereas private buildings have an energy saving potential of $35 \%-60 \%$.

The study results indicate that the EPI of government buildings is lower than that of the private buildings possibly because government buildings have a high WWR, with no shading devices, whereas office equipment is excessively used in private offices. The average EPI of the 
selected government and private offices is 136 and $217 \mathrm{kWh} / \mathrm{m}^{2} /$ year, respectively. The average working area per person in the buildings is 10 $\mathrm{m}^{2}$, which is approximately the value prescribed by ASHRAE (ANSI/ASHRAE/IES Standard 90.1, 2010).

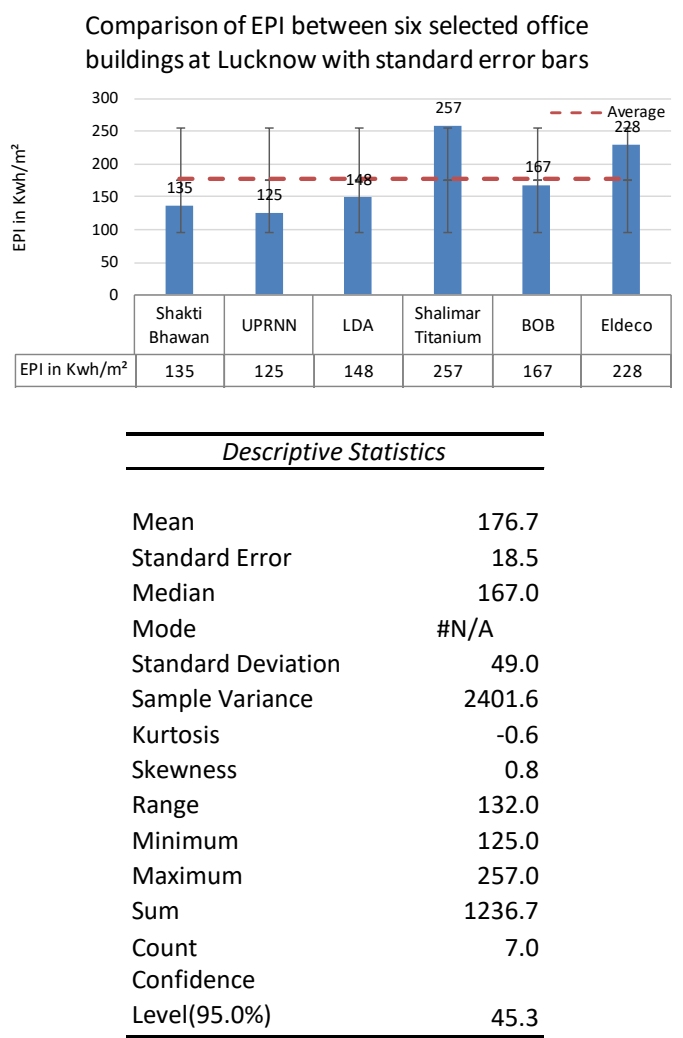

Figure 5. Comparison of the EPI of the six selected office buildings in Lucknow

\section{CONCLUSION}

The energy consumption of six office buildings in Lucknow was studied to determine energy consumption and factors affecting energy usage. These six buildings represent a sample of all commercial buildings that will be built in Lucknow in the future. The EPI of these buildings was relatively high, and considerable energy savings can be achieved by incorporating energy conservation measures at the early stage of construction. Hence, to decrease energy consumption in high-rise office buildings, the following design strategies are proposed:

1. The orientation of the building should be north-south. Despite having a high WWR and being fully air-conditioned, the energy consumption of Eldeco Corporate Chamber II was lower than that of Shalimar Titanium probably because of the north-south orientation of the Eldeco building.

2. The aspect ratio of the building plan and $\mathrm{S} / \mathrm{V}$ ratio influence heat gain and loss through the envelope. The compact planning (square shape) of the $\mathrm{BOB}$ and UPRNN buildings may be the reason for their low EPI. Furthermore, the presence of a courtyard at the center of the plan (the BOB and UPRNN buildings) allows daylight to cover a large area of the building, which can be an effective method to reduce energy consumption.

3. Dividing internal space into areas with different temperatures could reduce the cooling or heating load of high-rise buildings because a high degree of comfort is required at workstations, whereas some discomfort can be tolerated at lift lobbies and circulation spaces. Consequently, spaces, such as corridors, staircases, and lift lobbies, can be naturally ventilated, thereby reducing the load on the HVAC system, as seen from the case studies of government office buildings.

4. Devising an optimum WWR is critical to minimize heat transfer and maximize daylight in interiors. Government office buildings, with WWRs ranging from $20 \%$ to $30 \%$ and including shaded windows, had lower energy consumption than private office buildings.

5. High thermal mass or insulation in the walls or roofs (Shakti Bhawan) is an effective method to reduce heat transfer in buildings. Moreover, placing service areas as thermal buffers on hot sides with limited openings (Eldeco) and using reflective external materials (selected cases of private office buildings) are some of the strategies to control heat gain.

The energy usage of the three private office buildings in this case study should be thoroughly investigated further, and other energy indices should be identified as vital components of the energy management program. 


\section{REFERENCES}

ASHRAE. (2010). ANSI/ASHRAE/IES Standard 90.1: Energy Standard for Buildings except low rise residential Building. Atlanta: ANSI/ASHRAE/IES.

Bassi, S. (2015). Energy-efficiency improvements. In S. N. Srinivas (Ed.), Implementing Energy Efficiency in Buildings, A compendium of experiences from across the world, International Conference on Energy Efficiency in Buildings (ICEEB 2015) 17 - 18 December (pp. 99-106). New Delhi: BEE, Government of India. Retrieved March 07, 2017 , from http://www.undp.org/content/dam/india/do cs/ICEEB\%202015_Compendium.pdf

ECBC User Guide v 2.0. (2011, Aril 01). Retrieved 6 2015, 16, from Energy Conservation Building Code: http://www.eco3.org/wp-content/plugins/. ECBC User Guide v 2.0

Esfandiari, M., Zaid, S. M., \& Ismail, M. A. (2017). Investigating the Indoor Environment Quality Parameters and Their Relationship with Occupants' Satisfaction in Office Buildings: A Review. Journal of Design and Built Environment, 181-194. Retrieved from http://mjs.um.edu.my/index.php/jdbe/articl e/download/10156/7202

Ismail, L. H. (2007). An evaluation of bioclimatic high rise office buildings in a tropical climate: energy consumption and users' satisfaction in selected office buildings in Malaysia. Liverpool: Ph.D Thesis, School of Architecture, University of Liverpool.

Ismail, L. H., \& Sibley, M. (2006). Bioclimatic Performance of High Rise Office Buildings: A Case Study in Penang Island. PLEA2006 - The 23rd Conference on Passive and Low Energy Architecture, 6-8 September 2006. Geneva, Switzerland. Retrieved February 01, 2018, from https://www.researchgate.net/profile/Lokm an_Ismail/publication/290174887_Bioclim atic_performance_of_high_rise_office_buil dings_A_case_study_in_Penang_Island/lin ks/5784439f08ae3f355b4a4071/Bioclimati c-performance-of-high-rise-officebuildings-A-case-study-

Koenigsberger, O. H., Ingersoll, T. G., Mayhew, , A., \& Szokolay, S. V. (1974). Manual of tropical housing and building. Part one: Climatic design. Chennai: Orient Longman Pvt. Limited.

Mahdavi, A., Rao, S. P., \& Inangda, N. (2013). Parametric Studies on Window-To-Wall Ratio for Day lighting Optimisation in High-Rise Office Buildings in Kuala Lumpur,Malaysia. Journal of Design and Built Environment 12(1), 1-8. Retrieved April 18, 2020, from http://mjs.um.edu.my/index.php/jdbe/articl e/download/5332/3121

Olgyay, V. (1962). Design with Climate: Bioclimatic Approach to Architectural Regionalism. New Jersey: Princeton University Press.

Raji, B., Tenpierik, M. J., \& Dobbelsteen, A. v. (2016). A Comparative Study: Design Strategies for Energy-Efficiency of HighRise Office Buildings. Journal of Green building, 11(1), 134-158. doi:doi:10.3992/jgb.11.1.134.1

Srinivas, S. N. (2015). Energy-efficiency improvements in commercial buildings in India. Implementing Energy Efficiency in Buildings, A compendium of experiences from across the world, International Conference on Energy Efficiency in Buildings (ICEEB 2015) $17 \quad-18$ December 2015 (pp. 3-13). New Delhi: BEE, Government of India. Retrieved March 207, 2017, from http://www.undp.org/content/dam/india/do cs/ICEEB\%202015_Compendium.pdf

Szokolay, S. V. (2014). Introduction to Architectural Science- The Basis of Sustainable Design. London and New York: Routledge Taylor \& Francis Group.

Tahir, M. Z., Nawi, N. M., \& Rajemi, M. F. (2015). Building Energy Index: A Case Study of Three Government Office Buildings in Malaysia. Advanced Science Letters, Vol. 21(6), 1799-1802. doi:10.1166/asl.2015.6239

UP Power Corporation Limited. (2015). Statistics at a Glance-2014-15. . Lucknow: Planning wing, UP Power Corporation Limited. 